\title{
ОЦІНКА ЯКІСНИХ ПОКАЗНИКІВ МОЛОКА КОРІВ ТА ЇХ ВЗАЄМОЗВ'ЯЗОК ЗАЛЕЖНО ВІД ПЕРІОДУ ЛАКТАЦІї
}

\author{
Омелькович Світлана Петрівна \\ кандидат сільськогосподарських наук, доцент \\ Поліський національний університет \\ ORCID: 0000-0002-9581-0043 \\ E-mail: svetazt1911@gmail.com \\ Шуляр Аліна Леонідівна \\ кандидат сільськогосподарських наук \\ Поліський національний університет \\ ORCID: 0000-0002-8462-2135 \\ E-mail: kvitkashu777@gmail.com \\ Шуляр Альона Леонідівна \\ кандидат сільськогосподарських наук \\ Поліський національний університет \\ ORCID: 0000-0002-0823-6814 \\ E-mail: alyonashulyar7@gmail.com
}

Представлено результати оцінки впливу періоду лактації на мінливість ознак молочної продуктивності корівпервісток української чорно-рябої молочної породи. Було визначено добовий надій, вміст жиру, білка, сухий знежирений молочний залишок та густину молока. У обстежених корів пік надою припадає на третій місяць лактації. Максимальне значення показника густини молока спостерігається на 3-4 місяиях лактації, мінімальна - на 1 місяиі. За два перших місяці лактації первісток отримують четверту частину, за три - біля 40\% загальної молочної продукиії за 305 днів лактації, що підвищує надійність відбору тварин за зазначені 2-3 їі перші місяці. Вміст в молоці сухого знежиреного молочного залишку змінювався упродовж лактації криволінійно: його середнє значення на 1-3 місяиях склало 8,47; на 4-7 8,22 і на 8-10 - 8,56\%. Що стосується густини молока, то цей показник виявився досить стабільним $і$ коливався по місяиях лактації в межах 27,4-28,3 Ао. Встановлено зв'язок між надоєм та якісними характеристиками молока. Найнадійнішим для відбору корів за надоєм є період на 3-9 місяцях лактації, за вмістом жиру в молоці - 1-3 місяць, білка 2-4, сухим знежиреним молочним залишком - 5-7, густиною молока - 1-3 місяиі. Низькоінформмативними для прогнозування якісних параметрів молока за 305 днів є показники, отримані за останні 3-4 місяиі лактації. Проведено також обрахунок рівня зв'язку між ознаками за перші два, три місяиі лактації, а також за всю лактацію (10 місяиів). Аналіз цих результатів свідчить також про те, що оцінка корів-первісток за перші 60 днів лактації є досить надійною для їх об'єктивного відбору. Достовірність коефіцієнтів кореляиії між ознаками молочної продуктивності, отриманими за 10 місяців лактації знижується від першого до останнього, що ще раз підтверджує доцільність проведення оцінки генетичного потенціалу корів на початкових стадіях лактації, які детермінуються, в основному, біологічною домінантою збереження виду.

Ключові слова: корова, якісний склад молока, надій, період лактації, мінливість, взаємозв'язок, українська чорноряба молочна порода.

DOI: https://doi.org/10.32845/bsnau.lvst.2021.2.16

Сучасні умови ринку як нашої країни, так і вихід на ринки інших держав диктують свої вимоги до молочної сировини. Основними з яких є постійний її об'єм при стабільно високій якості $[4,10]$.

В оновлених ДСТУ «3662:2018 Молоко коров'яче. Технічні умови» крім інших змін, змінюються вимоги до молока другого ґатунку, що ставить перед виробниками ще серйозніші питання в отриманні продукції вищої якості [3].

Рівень реалізації продуктивності корів та складових молока залежить від багатьох факторів, а саме: породи, генетичного потенціалу тварин, годівлі, технології утримання, обраного напрямку селекції $[2,6,7,8,12,13,14,15]$. Мінімалізація впливу паратипових факторів, збалансована цілорічна годівля, новітні технології отримання та зберігання молока - необхідні складові сучасної технології ведення галузі. Оцінка якісних показників молока була і залишиться важливою складовою будь-якої галузі тваринництва, направленої на виробництво молока $[1,5,10]$.
3 огляду на це, питання вивчання якісних складових молока корів сучасних порід є вельми актуальним.

Матеріали та методи досліджень. Об'єктом досліджень є 107 корів української чорно-рябої молочної породи ПСП «Україна» Попільнянського району Житомирської області, які закінчили першу лактацію. Предмет досліджень: надій, склад молока (жир, білок, сухий знежирений молочний залишок - СЗМЗ) та його густина. Методика досліджень. Надій корів визначали за результатами цілодобових контрольних доїнь один раз в місяць, починаючи з 15 дня лактації, вміст в добових зразках жиру, білка, СЗМЗ визначали щомісячно на приладі «Екомілк КАМ-98.2А» болгарського виробництва. Густину молока визначали молочним ареометром (лактоденсиметром) і виражали її в одиницях ареометра $\left(\mathrm{A}^{\circ}\right)$. Первинні дані опрацьовані методами варіаційної статистики (М. О. Плохінський, 1969). При цьому обчислені середні величини досліджуваних показників та їх похибки $(\mathrm{M} \pm \mathrm{m})$, їх мінливість $\left(\mathrm{C}_{\mathrm{v}}\right)$ та повто- 
рюваність $\left(r_{w}\right)$, коефіцієнти фенотипової кореляції $\left(r_{p}\right)$ з урахуванням трьох порогів достовірності: $\mathrm{P}<0,05\left(^{*}\right), \mathrm{P}<0,01$ $\left({ }^{* *}\right), P<0,001\left(^{* * *}\right)$.

Результати досліджень. У обстежених корів пік надою припадає на третій місяць лактації, мінімум - на 10-й (табл. 1). Середньодобові і місячні надої зменшились протя- гом десяти місяців лактації в 2,2 раза. Мінімальний надій на 10-му місяці лактації у порівнянні з максимальним (III місяць) склав 55,6\%. Різниця за середньодобовим надоєм між цими місяцями становить 9,5 кг (P<0,001). Аналогічна динаміка спостерігається і за місячними надоями.

Динаміка надою та якісних показників молока корів-первісток

\begin{tabular}{|c|c|c|c|c|c|c|c|c|c|c|c|c|}
\hline \multirow{2}{*}{$\begin{array}{c}\text { Показник, одиниця } \\
\text { виміру }\end{array}$} & \multicolumn{10}{|c|}{ Місяці лактації } & \multicolumn{2}{|c|}{ В т.ч. за перші: } \\
\hline & 1 & 2 & 3 & 4 & 5 & 6 & 7 & 8 & 9 & 10 & $60 \mathrm{gH}$ & $90 \mathrm{gH}$ \\
\hline Добовий надій, кг & $\begin{array}{c}15,4 \pm \\
0,51\end{array}$ & $\begin{array}{c}16,2 \pm \\
0,56\end{array}$ & $\begin{array}{c}17,2 \pm \\
0,74\end{array}$ & $\begin{array}{c}14,8 \pm \\
0,53\end{array}$ & $\begin{array}{c}14,2 \pm \\
0,51\end{array}$ & $\begin{array}{c}13,5 \pm \\
0,45\end{array}$ & $\begin{array}{c}12,3 \pm \\
0,45\end{array}$ & $\begin{array}{c}11,2 \pm \\
0,43\end{array}$ & \begin{tabular}{|l|}
$9,5 \pm$ \\
0,42
\end{tabular} & $\begin{array}{l}7,7 \pm \\
0,46\end{array}$ & $\begin{array}{c}31,6 \pm \\
0,46\end{array}$ & $\begin{array}{c}48,8 \pm \\
0,36\end{array}$ \\
\hline Місячний надій, кг & $\begin{array}{c}471 \pm \\
15,6\end{array}$ & $\begin{array}{c}495 \pm \\
17,1\end{array}$ & $\begin{array}{c}524 \pm \\
22,5\end{array}$ & $\begin{array}{c}451 \pm \\
16,1\end{array}$ & $\begin{array}{c}434 \pm \\
15,6\end{array}$ & $\begin{array}{r}412 \pm \\
14,2\end{array}$ & $\begin{array}{c}374 \pm \\
13,7\end{array}$ & $\begin{array}{c}342 \pm \\
13,0\end{array}$ & \begin{tabular}{|c|}
$291 \pm$ \\
12,6
\end{tabular} & $\begin{array}{c}236 \pm \\
14,1\end{array}$ & $\begin{array}{c}965 \pm \\
11,2\end{array}$ & $\begin{array}{c}1489 \pm \\
10,9\end{array}$ \\
\hline $\mathrm{C}_{\mathrm{v}}, \%$ & 18,1 & 19,0 & 23,6 & 19,6 & 19,7 & 18,8 & 20,1 & 20,8 & 24,0 & 32,9 & 10,9 & 6,9 \\
\hline Жирномолочність,\% & $\begin{array}{c}4,43 \pm \\
0,10\end{array}$ & $\begin{array}{c}3,72 \pm \\
0,08\end{array}$ & $\begin{array}{c}3,51 \pm \\
0,04\end{array}$ & $\begin{array}{c}3,37 \pm \\
0,03\end{array}$ & $\begin{array}{c}3,36 \pm \\
0,01\end{array}$ & $\begin{array}{c}3,30 \pm \\
0,01\end{array}$ & $\begin{array}{c}3,36 \pm \\
0,01\end{array}$ & $\begin{array}{c}3,38 \pm \\
0,01\end{array}$ & $\begin{array}{c}3,44 \pm \\
0,01\end{array}$ & $\begin{array}{c}3,49 \pm \\
0,01\end{array}$ & $\begin{array}{c}4,08 \pm \\
0,08\end{array}$ & $\begin{array}{c}3,89 \pm \\
0,06\end{array}$ \\
\hline $\mathrm{C}_{\mathrm{v}}, \%$ & 12,2 & 11,2 & 6,3 & 4,3 & 2,2 & 2,0 & 2,2 & 1,8 & 2,0 & 2,4 & 14,6 & 14,7 \\
\hline Білковомолочність,\% & $\begin{array}{c}3,21 \pm \\
0,02\end{array}$ & $\begin{array}{c}3,19 \pm \\
0,02\end{array}$ & $\begin{array}{c}3,18 \pm \\
0,02\end{array}$ & $\begin{array}{c}3,07 \pm \\
0,01\end{array}$ & $\begin{array}{c}3,02 \pm \\
0,02\end{array}$ & $\begin{array}{l}2,95 \pm \\
0,012\end{array}$ & $\begin{array}{c}2,96 \pm \\
0,01\end{array}$ & $\begin{array}{c}3,02 \pm \\
0,01\end{array}$ & $\begin{array}{c}3,06 \pm \\
0,01\end{array}$ & $\begin{array}{c}3,10 \pm \\
0,01\end{array}$ & $\begin{array}{c}3,20 \pm \\
0,01\end{array}$ & $\begin{array}{c}3,19 \pm \\
0,01\end{array}$ \\
\hline $\mathrm{Cv}, \%$ & 3,4 & 4,0 & 3,3 & 2,4 & 2,8 & 2,2 & 2,8 & 1,4 & 1,7 & 1,6 & 3,7 & 3,6 \\
\hline Вміст СЗМЗ, \% & $\begin{array}{c}8,49 \pm \\
0,06\end{array}$ & $\begin{array}{c}8,44 \pm \\
0,07\end{array}$ & $\begin{array}{c}8,48 \pm \\
0,04\end{array}$ & $\begin{array}{c}8,39 \pm \\
0,06\end{array}$ & $\begin{array}{c}8,30 \pm \\
0,07\end{array}$ & $\begin{array}{c}8,24 \pm \\
0,07\end{array}$ & $\begin{array}{c}7,98 \pm \\
0,12\end{array}$ & $\begin{array}{c}8,49 \pm \\
0,04\end{array}$ & \begin{tabular}{|c}
$8,53 \pm$ \\
0,03
\end{tabular} & $\begin{array}{c}8,67 \pm \\
0,03\end{array}$ & $\begin{array}{c}8,46 \pm \\
0,04\end{array}$ & $\begin{array}{c}8,47 \pm \\
0,03\end{array}$ \\
\hline $\mathrm{C}_{\mathrm{v}}, \%$ & 3,6 & 4,2 & 2,8 & 3,6 & 4,7 & 4,8 & 8,4 & 2,3 & 1,9 & 1,8 & 3,9 & 3,5 \\
\hline Густина молока,Ао & $\begin{array}{c}27,4 \pm \\
0,23 \\
\end{array}$ & $\begin{array}{c}27,9 \pm \\
0,26\end{array}$ & $\begin{array}{c}28,3 \pm \\
0,16\end{array}$ & $\begin{array}{c}28,3 \pm \\
0,13\end{array}$ & $\begin{array}{c}28,1 \pm \\
0,13\end{array}$ & $\begin{array}{c}28,1 \pm \\
0,10 \\
\end{array}$ & $\begin{array}{c}28,2 \pm \\
0,11\end{array}$ & $\begin{array}{c}28,2 \pm \\
0,12 \\
\end{array}$ & $\begin{array}{c}28,1 \pm \\
0,08\end{array}$ & $\begin{array}{c}28,1 \pm \\
0,09\end{array}$ & $\begin{array}{c}27,7 \pm \\
0,18\end{array}$ & $\begin{array}{c}27,9 \pm \\
0,13\end{array}$ \\
\hline $\mathrm{C}_{\mathrm{v},}, \%$ & 4,6 & 5,2 & 3,1 & 2,6 & 2,5 & 1,9 & 2,1 & 2,2 & 1,6 & 1,8 & 4,9 & 4,5 \\
\hline
\end{tabular}

Упродовж лактації коефіцієнт мінливості надою $\left(\mathrm{C}_{\mathrm{v}}\right)$ змінюється криволінійно: до другого-третього місяця він дещо зростає (до 23,6\%), потім знижується (18,8\%) і знову зростає, досягаючи $32,9 \%$ наприкінці лактації.

Що стосується вмісту жиру і білка в молоці, то ці показники упродовж лактації змінюються неординарно: вони в основному зменшуються до 4-7 місяця лактації, а потім знову дещо зростають. Так, середній вміст жиру в молоці обстежених тварин по перших трьох місяцях лактації склав, у середньому, 3,89; 4-7 міс - 3,35; 8-10 міс - 3,44\%, білка відповідно 3,19; 3,00 і 3,06\%, при достовірній різниці між крайніми періодами. Ці зміни можуть бути зумовлені двома причинами - генетико-біологічною (від'ємною генетичною кореляцією «надій - вміст жиру і білка в молоці») і паратиповою (наприклад, погіршення умов годівлі та утримання корів після переміщення їх із цеху отелення в цех виробництва молока).

Спостерігається також різке зниження упродовж лактації мінливості цих молочних компонентів. У порівнянні $з$ першим місяцем лактації коефіцієнт варіації жирномолочності знизився на 10-му місяці в 5,1 рази і склав 2,4\%; білковомолочності - відповідно в 2,1 рази і 1,6\%. Цю особливість можна пояснити зазначеними вище причинами, що призводить до прогресуючого протиріччя «генотип-середовище».

Вміст у молоці сухого знежиреного молочного залишку коливається по місяцях лактації у обстежених корів від 7,98 до 8,67\% (різниця 0,69\%, Р<0,001). Цей показник змінювався впродовж лактації криволінійно: його середнє значення на 1-3 місяцях лактації склало 8,47; на 4-7 - 8,22 і на 8-10 - 8,56\%, що обумовлено особливостями динаміки складових цього показника (білок, лактоза, мінеральні речовини, вітаміни, гормони та ін.).

Що стосується густини молока, то цей показник виявився досить стабільним і коливався по місяцях лактації в межах 27,4-28,3 Ao (d=0,9, $P<0,01)$. Максимальне значення показника густини молока спостерігається на 3-4 місяцях лактації (28,3), мінімальна - на 1 місяці $(27,4$ А०).

3 метою підвищення результативності масового відбору тварин та усунення необгрунтованих витрат на утримання низькопродуктивних корів, їх оцінку за власними показниками здійснюють за перші 2-3 місяці лактації.

Надій обстежених корів становив за перший місяць лактації в середньому 471 кг або 11,0\%, за два перших місяці - відповідно 964,4 кг і 22,7\%, за три - 1488,9 кг і 37,0\% від значення за 305 днів лактації.

Тобто, за два перших місяці отримують четверту частину, за три - біля 40\% загальної молочної продукції за 305 днів лактації, що підвищує надійність відбору тварин за зазначені 2-3 її перші місяці.

Про це переконливо свідчить наведений нижче кореляційний аналіз (табл. 2).

Таблиця 2

Надійність відбору корів за перші три місяці лактації

\begin{tabular}{|c|c|c|c|}
\hline \multirow{2}{*}{ Ознаки } & \multicolumn{3}{|c|}{ 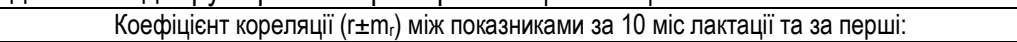 } \\
\hline & 30 днів & 60 днів & 90 днів \\
\hline Надій, кг & $+0,511 \pm 0,1624^{* *}$ & $+0,490 \pm 0,1647^{* *}$ & $+0,693 \pm 0,1362^{* * *}$ \\
\hline Вміст жиру, \% & $-0,083 \pm 0,1883$ & $-0,110 \pm 0,1878$ & $-0,184 \pm 0,1857$ \\
\hline Вміст білка, \% & $-0,537 \pm 0,1594^{* *}$ & $-0,439 \pm 0,1698^{*}$ & $-0,475 \pm 0,1663^{\star *}$ \\
\hline Вміст СЗМЗ, \% & $-0,358 \pm 0,1765^{*}$ & $-0,407 \pm 0,1726^{*}$ & $-0,324 \pm 0,1788$ \\
\hline Густина молока, $A^{\circ}$ & $-0,043 \pm 0,1888$ & $-0,103 \pm 0,1880$ & $-0,165 \pm 0,1864$ \\
\hline
\end{tabular}


До речі, потрібно зауважити, що показники за перші 30 днів лактації надійніші для відбору корів за лактацію, ніж за 60 днів. Проте максимальні коефріцієнти кореляції з параметрами повної лактації (за 305 днів) отримані по надою за 90 облікових днів $(+0,693)$, проти відповідно +0,490 за 60 днів лактації.

В селекції молочної худоби особливе значення має повторюваність щомісячних оцінок надою та його компонентів з аналогічними показниками за 305 днів лактації. Коефіцієнт повторюваності $\left(\mathrm{r}_{\mathrm{w}}\right)$ дає можливість визначити найоптимальніші періоди оцінки корів за параметрами молочної продуктивності протягом нормального (305 днів і більше) лактаційного періоду.

Результати дослідження свідчать про те, що не всі компоненти молочної продуктивності корів в однаковій мірі взаємозв'язані з показниками за 305 днів лактації (табл. 3).

Найнадійнішими для відбору корів за надоєм є значення цієї ознаки на 3-9 місяцях лактації: коесріцієнти кореляції коливалися в межах +0,725 - +0,921 ( $\mathrm{P}<0,001)$. Для загальної оцінки корів за вмістом жиру в молоці найнадійнішими є показники за 1-3 місяці лактації, білка - 24, С3М3 - 5-7, густини молока - 1-3 місяці. Низькоінформативними для оцінки якісних параметрів молока за 305 днів $\epsilon$ показники, отримані за останні 3-4 місяці лактації.।

Обраховані нами фенотипові кореляції $\left(r_{p}\right)$ між різними компонентами молочної продуктивності за перший місяць лактації коливалися в широких межах: від -0,276 (жирність-густина молока) до +0,993 (Р<0,001) (білокC3M3).

Отже, густина молока визначається, в основному, вмістом в ньому С3М3, а С3М3 - вмістом білка. Аналогічна залежність спостерігається на другому $(-0,256$ і 0,983(P<0,001) і третьому $(+0,109$ i $+0,603$ ( $P<0,001)$ місяцях лактації. Проте в цілому за лактацію ці коефріцієнти дещо нижчі.

Проведено також обрахунок рівня зв'язку між ознаками за перші два, три місяці лактації, а також за всю лактацію (10 місяців).

Таблиця 3

Повторюваність оцінок ознак молочної продуктивності по місяцях лактації

\begin{tabular}{|c|c|c|c|c|c|c|}
\hline \multirow{3}{*}{ Місяці лактації } & \multicolumn{6}{|c|}{ Кореляція $\left(\mathrm{r}_{\mathrm{w}}\right)$ з параметрами за 305 днів за ознаками: } \\
\hline & \multirow{2}{*}{ добовий надій, кг } & \multirow{2}{*}{ місячний надій, кг } & \multicolumn{3}{|c|}{ вміст в молоці, \% } & \multirow{2}{*}{ густина молока,А० } \\
\hline & & & жиру & білка & C3M3 & \\
\hline 1 & $+0,511^{* *}$ & $+0,511$ & $+0,620$ & $+0,129$ & $+0,233$ & $+0,590$ \\
\hline 2 & $+0,288$ & $+0,288$ & $+0,776$ & $+0,533$ & $+0,129$ & $+0,647$ \\
\hline 3 & $+0,850$ & $+0,850^{* * *}$ & $+0,476$ & $+0,777$ & $+0,583$ * & $+0,543$ \\
\hline 4 & $+0,819^{* * *}$ & $+0,819^{* * *}$ & $+0,302$ & $+0,566^{* *}$ & $+0,528$ & $+0,471$ \\
\hline 5 & $+0,725$ & $+0,725^{* * *}$ & $+0,515$ & $+0,285$ & $+0,837$ * & $+0,479$ \\
\hline 6 & $+0,877^{* \star *}$ & $+0,877^{* * *}$ & $+0,395$ & $+0,337$ & $+0,707^{*}$ & $+0,118$ \\
\hline 7 & $+0,878$ & $+0,878^{* * *}$ & $+0,321$ & $+0,184$ & $+0,661$ & $+0,465$ \\
\hline 8 & $+0,921^{* \star *}$ & $+0,921^{* \star \star}$ & $+0,253$ & $+0,225$ & $+0,266$ & $+0,182$ \\
\hline 9 & $+0,820$ & $+0,820$ & $-0,030$ & $+0,170$ & $-0,397$ & $+0,230$ \\
\hline 10 & $+0,664$ & $+0,664$ & $+0,137$ & $+0,075$ & $-0,091$ & $+0,163$ \\
\hline
\end{tabular}

Так, рівень взаємозв'язку між відсотком жиру і сухим знежиреним молочним залишком відповідно склав -0,083, $+0,02$ i +0,014; з густиною молока відповідно -0,411 ( $<<0,05)$, -0,271 і -0,175; відсотком білка і сухим знежиреним молочним залишком - +0,989 ( $\mathrm{P}<0,001),+0,925(\mathrm{P}<0,001)$ i $+0,528$ $(\mathrm{P}<0,01) ; \quad 3$ густиною молока відповідно +0,933 $(\mathrm{P}<0,001)$, $+0,899(P<0,001)$ i $+0,585(P<0,001)$. Аналіз цих результатів свідчить також про те, що оцінка корів-первісток за перші 60 днів лактації є досить надійною для їх об'єктивного відбору. Це дуже важливо. Адже перетримка корів в селекційному корівнику призводить до додаткових витрат на їх оцінку.

Достовірність коефіцієнтів кореляції між ознаками молочної продуктивності, отриманими за 10 місяців лактації знижується від першого до останнього, що ще раз підтверджує доцільність проведення оцінки генетичного потенціалу корів на початкових стадіях лактації, які детермінуються, восновному, біологічною домінантою збереження виду.

Висновки. 1. Корови української чорно-рябої породи добре роздоюються. За два перших місяці від них отримують четверту частину, а за три - біля 40\% загальної молочної продукції за 305 днів лактації.

2. Вміст жиру і білка в молоці упродовж лактації змінювався неоднаково: до 4-7 місяця він зменшувався, а потім дещо зростав.

3. Вміст в молоці СЗМ3 змінювався упродовж лактації криволінійно: його середнє значення на 1-3 місяцях склало 8,47; на 4-7 - 8,22 і на 8-10 - 8,56\%.

4. Компоненти молочної продуктивності корів за окремі відрізки лактації не в однаковій мірі взаємозв'язані з показниками за 305 днів. Найнадійнішим для відбору корів за надоєм є період на 3-9 місяцях лактації, за вмістом жиру в молоці - 1-3 місяць, білка - 2-4, СЗМ3 - 5-7, густини молока - 1-3 місяці. Низькоінформативними для прогнозування якісних параметрів молока за 305 днів є показники, отримані за останні 3-4 місяці лактації. 


\section{Список використаної літератури:}

1. Афанасенко В. Ю., Федота О. М. Оцінка зміни якісного складу молока корів в залежності від періоду лактації. $\underline{\text { Po- }}$ зведення і генетика тварин. 2015. Вип. 49. С. 63-68.

2. Бахтиярова О. В. Влияние условий кормления на характер лактационных кривых коров-первотелок. Известия Академии аграрных наук Республики Беларусь. 2000. № 3. С. 66-69.

3. В Україні почав діяти новий стандарт якості молока. URL:https://agravery.com/uk/posts/show/v-ukraini-pocav-diatinovii-standart-akosti-moloka (дата звернення: 10.03. 2021).

4.Ємцев В. І. Стан та перспективи розвитку ринку молока в Україні. Fundamental and applied research in the modern world. Boston, USA 18-20 November 2020. P. 498-505.

5. Зубченко В. В. Якість молока як основний чинник забезпечення конкурентоспроможності продукції. Вісник аграрної науки. 2011. №4. С. 79-82.

6. Ковальчук Т. І. Якісний склад молока корів різних порід. Тваринниитво України. 2014. № 3-4. С. 8-10.

7. Логинов Ж. Г., Рахматулина Н. Р., Улимбашев А. М. Показатель постоянства лактации как признак при комплексной оценке племенной ценности коров. Зоотехния. 2008. № 10. С. 4-7.

8. Пелехатий М. С., Омелькович С. П. Молочна продуктивність корів української чорно-рябої молочної породи різних виробничих типів. Науковий вісник Національного університету біоресурсів і природокористування України. 2010. № 138. C. $98-106$.

9. Плохинский Н. А. Руководство по биометрии для зоотехников. Москва: Колос, 1969. 256 с.

10. Проблеми якості питного молока різних товаровиробників / І. В. Донцова, Л. І. Гірняк, В. Т. Лебединиць, М. П. Бодак. Вісник Львівської комерційної академії. Серія товарознавча. 2011. Вип. 12. С. 102-107.

11. Тивончук С. В., Тивончук Я. О. Світовий ринок молока і молочних продуктів: особливості фрормування та тенденції розвитку. Вісник аграрної науки Причорномор'я. 2014. Вип. 2 (78).С. 57-64

12. Троценко 3. Г. Основні напрями підвищення продуктивності стада великої рогатої худоби української чорно-рябої молочної породи. Вісник аграрної науки. 2015. С. 70-73.

13. Toledo-Alvarado H. Cecchinato A., Bittante G. Fertility traits of Holstein, Brown Swiss, Simmental, and Alpine Grey cows are differently affected by herd productivity and milk yield of individual cows. Journal of Dairy Science. 2017. Vol. 100. Is. 10. P. 8220-8231.

14. Variation of milk, fat, protein, and somatic cells for dairy cattle / M. M. Schutz, L. B. Hansen, G. R. Steuernagel, A. L. Kuck. Journal of Dairy Science.1990.Vol. 73. Is. 2. P. 484-493.

15. Wright J. A., Rook A. F., Wood P. D. P. The responses in milk solids-not-fat and protein contents to improved feeding of cows receiving winter-stall diets and underfed for varying period. Journal of Dairy Science. 1974. Vol. 41. Is. 2.P. 155-164.

\section{References:}

1.Afanasenko, V. Y. and Fedota, O. M. 2015. Otsinka zminu yakisnogo skladu moloka koriv v zalejnosti vid period laktacii Evaluation of changes of composition of the milk of cows depending on the period of lactation. Rozvedennya $i$ genetuka tvarun [Breeding and genetics of animals]. 49: 63-68.

2.Bahtijarova, O. V. 2000. Vliyanie usloviy kormleniya na harakter laktatsionnuh krivyh - Influence of feeding conditions on the nature of the lactation curves of first-calf heifers. Izvestija Akademii agrarnyh nauk Respubliki Belarus'.3: 66-69.

3.V Ukraini pochav diyatu novuy standart yacosti moloka - A new milk quality standard has come into force in Ukraine: URL :https://agravery.com/uk/posts/show/v-ukraini-pocav-diati-novii-standart-akosti-molokal

4. Yemcev, V. I. 2020.Stan ta perspektuvu rozvutky runky moloka v Ykraini - Situation and prospects of the development of the milk and dairy products in Ukraine. Fundamental and applied research in the modern world.Boston, USA 18-20 November 2020. 498-505.

5.Zubchenko, V. V. 2011. Yakist' moloka yak osnovnuy chinnuk zabezpechennya konkurentospromozhnosti produktsiyi The quality of the milk as the main factor ensuring the competitiveness of products. Visnyk ahrarnoyi nauky.[Bulletin of agricultural science]. 4: 79-82.

6.Koval'chuk, T. I. 2014. Yakisnyy sklad moloka koriv riznykh porid - Quality of cows ofdifferent breeds. Tvarynnytstvo Ukrayini [Livestock of Ukraine]. 3-4: 8-10.

7.Loginov, Zh. G., Rakhmatulina, N. R. And Ulimbashev, A. M. 2008. Pokazatel' postoyanstva laktatsii kak priznak pri kompleksnoy otsenke plemennoy tsennosti korov - Indicator of constancy of lactation as a sign at a complex estimation of breeding value of cows. Zootekhniya [Zootechnics]. 10: 4-7.

8. Pelechatuy, M. S. and Omelkovich, S. P. 2010. Molochna prodyctivnost' koriv ukrayins'koyi chorno-ryaboi molochnoyi porodu riznyh vyrobnychnih typiv - Milking capacity of Ukrainian black-and-white dairy cows of various production types. Naukovyy visnyk Natsional'noho universytetu bioresursiv i pryrodokorystuvannya Ukrayiny [Scientific Bulletin of the National University of bioresources and nature management of Ukraine]. 138: 98-106.

9. Plohinskiy, N. A. 1969. Rukovodstvo po biometrii dlya zootexnikov -Biometrics guide for zootechnicians. Moskva: Kolos. 256.

10. Problemy yakisnogo gpytnogo moloka riznyh tovarovyrobnykiv - Problems of drinking milk quality of different producers. I. V. Dontsova, L. I. Girhyak, V. T. Lebedynyts', M. P. Bodak. Visnyk L'vivs'koyi komertsiynoyi akademii. Seriya tovaroznavcha [Bulletin of the Lviv Commercial Academy. Commodity series]. 12: 102-107.

11. Tyvonchuk, S. V. and Tyvonchuk Y. O. 2014. Svitovyy rynok moloka I molochnuh prodyktiv: osoblyvosti formuvannya ta 
tendentsii rozvytku - World market of milk and dairy products: features of formation and development trends. Visnyk agrarnoyi nauki Prichornomor'ya [Bulletin of Agrarian Science of the Black Sea Coast]. 2 (78): 7-64.

12. Trotsenco, Z. G. 2015. Osnovni napryamy pidvuschennya produktyvnosti stada velykoyi rogatoyi hudoby ukrayins'koyi chorno-ryaboi molochnoyi porodu. Visnyk agrarnoyi nauki [Bulletin of Agrarian Science]. 70-73.

13. Toledo-Alvarado, H. Cecchinato, A. and Bittante, G. Fertility traits of Holstein, Brown Swiss, Simmental, and Alpine Grey cows are differently affected by herd productivity and milk yield of individual cows. Journal of Dairy Science. 2017. Vol. 100. Is. 10. P. 8220-8231.

14. Variation of milk, fat, protein, and somatic cells for dairy cattle /M.M.Schutz, L.B.Hansen, G.R.Steuernagel, A.L.Kuck / Journal of Dairy Science. 1990.Vol. 73. Is. 2.P. 484-493.

15. Wright, J. A., Rook, A. F. and Wood, P. D. P. The responses in milk solids-not-fat and protein contents to improved feeding of cows receiving winter-stall diets and underfed for varying period. Journal of Dairy Science. 1974. Vol. 41. Is. 2. P. 155-164.

Omelkovych Svitlana Petrivna, Candidate of Agricultural Sciences (Ph.D.), Associate Professor

Shuliar Alina Leonidivna, Candidate of Agricultural Sciences (Ph.D.)

Shuliar Alona Leonidivna, Candidate of Agricultural Sciences (Ph.D.)

Polissya National University (Zhytomyr, Ukraine)

Evaluation of qualitative characteristics of a cow's milk and their correlation with the period of lactation

There were presented the results of influence of lactation period on variable characteristics of milk productivity in first-calving cows of Ukrainian black-and-white dairy breed. A daily milk yield, the contents of fat, protein, fat-dry milk residue, and milk density were determined. During lactation, a significant decrease in variability of fat and protein was observed. A correlation between milk yield and qualitative characteristics of milk was determined. The most reliable periods for selecting cows based on their milk yield was 3-9 months of lactation, based on fat content was 1-3 months, content of protein - 2-4, fat-dry milk residue - 5-7, density of milk - 1-3 months. In a 305-day period, the least informative characteristics for predicting qualitative parameters of milk were characteristics obtained during the last 3-4 months of lactation.

Key words: cow, qualitative content of milk, yield, lactation period, variability, correlation, Ukrainian black-and-white dairy breed.

Дата надходження до редакції: 07.04.2021 р. 